www.nature.com/jhg

\title{
Carrier frequency of GJB2 gene mutations c.35delG, c.235delC and c.167delT among the populations of Eurasia
}

\author{
Lilya U Dzhemileva ${ }^{1}$, Nikolay A Barashkov ${ }^{2}$, Olga L Posukh ${ }^{3}$, Rita I Khusainova ${ }^{1}$, Vita L Akhmetova ${ }^{1}$, \\ Ildus A Kutuev ${ }^{1}$, Irina R Gilyazova ${ }^{1}$, Vera N Tadinova ${ }^{4}$, Sardana A Fedorova ${ }^{2}$, Irina M Khidiyatova ${ }^{1}$, \\ Simeon L Lobov ${ }^{1}$ and Elza K Khusnutdinova ${ }^{1}$
}

\begin{abstract}
Hearing impairment is one of the most common disorders of sensorineural function and the incidence of profound prelingual deafness is about 1 per 1000 at birth. GJB2 gene mutations make the largest contribution to hereditary hearing impairment. The spectrum and prevalence of some GJB2 mutations are known to be dependent on the ethnic origin of the population. This study presents data on the carrier frequencies of major GJB2 mutations, c.35delG, c.167delT and c.235delC, among 2308 healthy persons from 18 various populations of Eurasia: Russians, Bashkirs, Tatars, Chuvashes, Udmurts, Komi-Permyaks and Mordvins (Volga-Ural region of Russia); Belarusians and Ukrainians (East Europe); Abkhazians, Avars, Cherkessians and Ingushes (Caucasus); Kazakhs, Uighurs and Uzbeks (Central Asia); and Yakuts and Altaians (Siberia). The data on c.35delG and c.235delC mutation prevalence in the studied ethnic groups can be used to investigate the prospective founder effect in the origin and prevalence of these mutations in Eurasia and consequently in populations around the world.
\end{abstract}

Journal of Human Genetics (2010) 55, 749-754; doi:10.1038/jhg.2010.101; published online 26 August 2010

Keywords: c.167delT; c.235delC; congenital deafness; connexin 26; GJB2; mutations c.35delG; populations of Eurasia

\section{INTRODUCTION}

Congenital deafness is one of the most frequent diseases that accounts for about 1 in 1000 newborns and approximately half of all cases have a genetic etiology. ${ }^{1,2}$ Hereditary forms of hearing loss are characterized by clinical polymorphism and genetic heterogeneity. To date, 114 loci and 55 genes have been described for inherited non-syndromic hearing impairment. ${ }^{3}$ About $75 \%$ of non-syndromic deafness cases are inherited as an autosomal recessive trait, $10-15 \%$ as autosomal dominant, low portion are $\mathrm{X}$-linked and some cases are caused by mitochondrial DNA mutations. ${ }^{2}$ Mutations of the GJB2 (gap junction protein beta 2) gene are the predominant cause of non-syndromic autosomal recessive deafness. The GJB2 gene is located on chromosome 13q11-q12 and encodes connexin 26 (Cx26)—a transmembrane protein that forms intercellular gap junction channels to allow ions and small molecules to transfer between adjacent cells. Mutations in the GJB2 gene (Cx26) lead to disturbance in ion homeostasis of the endolymph, which results in hearing impairment. ${ }^{4}$ To date, about 150 different mutations (mostly recessive), polymorphic variants and changes with unknown relation to the disease in GJB2 gene have been reported..$^{5}$ In many countries, up to $50 \%$ of recessive non-syndromic deafness can be attributed to mutations in the GJB2 gene. ${ }^{6}$ However, some important differences in carrier frequency of major recessive mutations in the GJB2 gene exist among various populations. The mutation c.35delG has been found with a high frequency in populations of Europe, Middle East and North America. ${ }^{7-10}$ Mutation c.235delC is found mainly in East Asian populations (Japanese, Chinese, Korean), and also in Mongolians and Altaians. ${ }^{11-16}$ Mutation c.167delT is widespread among Ashkenazi Jews and is found sporadically in some other populations. ${ }^{17-21}$ Mutation p.Trp24X is widespread in India ${ }^{22}$ and in the Romany (Gypsy) population (Eastern Europe). ${ }^{23}$ p.Arg143Trp is a major mutation in Ghana (West Africa), ${ }^{24}$ and mutation p.Val37Ile has the greatest prevalence in populations of Southeast Asia. ${ }^{25}$

The role of the founder effect in the origin and distribution of several mutations of the GJB2 gene was well established., $26-30$ Furthermore, novel hypotheses for the probable specific mechanism (combination of improved genetic fitness and assortative mating) for selective amplification of the commonest form of recessive deafness in the populations and of probable heterozygote advantage of GJB2 recessive mutations have been suggested. ${ }^{31,32}$ Data on the mutation spectrum and prevalence of major mutations of the GJB2 gene in various ethnic groups are very important for the development of

${ }^{1}$ Institute of Biochemistry and Genetics, Ufa Research Center, Russian Academy of Sciences, Ufa, Bashkortostan, Russian Federation; ${ }^{2}$ Yakut Research Center of Complex Medical Problems, Siberian Branch of the Russian Academy of Medical Sciences, Yakutsk, Russian Federation; ${ }^{3}$ Institute of Cytology and Genetics, Siberian Branch of the Russian Academy of Sciences, Novosibirsk, Russian Federation and ${ }^{4}$ Altai Republic Children's Hospital, Gorno-Altaisk, Russian Federation

Correspondence: Dr LU Dzhemileva, Department of Human Molecular Genetics, Institute of Biochemistry and Genetics, Ufa Research Center, Russian Academy of Sciences, Prospect Oktyabrya 71, Ufa, Bashkortostan 450054, Russian Federation.

E-mail: dzhemilev@anrb.ru

Received 18 May 2010; revised 16 July 2010; accepted 18 July 2010; published online 26 August 2010 
molecular diagnostics tools for identifying genetic causes of hereditary hearing loss; however, data on the prevalence of major GJB2 mutations in some populations are still not available.

We present here data on carrier frequencies of major GJB2 mutations, c.35delG, c.235delC and c.167delT, in 18 populations of Eurasia. In addition, the analysis of spatial distribution of c.35delG and c.235delC carrier frequencies among various populations of Eurasia, based on our own data and literature sources available at the end of 2009 , is presented.

\section{MATERIALS AND METHODS}

\section{DNA samples}

The total number of 2308 DNA samples of healthy unrelated individualsrepresentatives of 18 various ethnic groups living in the territory of Russia and in countries of the Former Soviet Union-have been studied in this study. These are Russians $(N=92)$, Belarusians $(N=97)$, Ukrainians $(N=90)$, Abkhazians $(N=80)$, Avars $(N=60)$, Cherkessians $(N=80)$, Ingushes $(N=80)$, Kazakhs $(N=240)$, Uighurs $(N=116)$, Uzbeks $(N=60)$, Bashkirs $(N=400)$, Tatars $(N=96)$, Chuvashes $(N=100)$, Udmurts $(N=80)$, Komi-Permyaks $(N=80)$, Mordvins $(N=80)$, Yakuts $(N=247 / 120)$ and Altaians $(N=230)$. The places of location of the populations under study are shown in Figure 1.

Blood samples were collected during research expeditions in 2000-2008. The ethnic origin (up to the third generation) was defined by direct interview with examined persons. For this research, all DNA samples studied were anonymized. Genomic DNA was isolated from peripheral blood leukocytes by a standard procedure of phenol-chloroform extraction.

\section{Mutation analysis}

Genotyping of c.35delG, c.167delT and c.235delC mutations of the GJB2 gene was performed by allele-specific amplification of the GJB2 coding region. To screen for the c.35delG mutation, the following primers were used:

F $5^{\prime}$-CTTTTCCAGAGCAAACCGCCC- $3^{\prime}$

R 5'-TGCTGGTGGAGTGTTTGTTCAC- $3^{\prime} .{ }^{33}$

The primers for detecting c.167delT and c.235delC mutations were designed at the Laboratory of Molecular Human Genetics (Institute of Biochemistry and Genetics, Ufa Research Center, Russian Academy of Sciences, Ufa, Russia):

167delT-F 5'-ATGAGCAGGCCGACTTTGTCTG-3',

167delT-R 5'-GTGGGAGATGGGGAAGTAGTGA-3',
235delC-F 5'-ACGATCACTACTTCCCCATCTC-3',

235delC-R 5'-ACTAGGAGCGCTGGCGTGGAC-3'.

PCR amplifications were performed with $1 \mu \mathrm{g}$ of genomic DNA, $5 \mu \mathrm{mol}$ of each forward and reverse primer, $10 \mathrm{~mm}$ Tris- $\mathrm{HCl}(\mathrm{pH} 8.8), 50 \mathrm{~mm} \mathrm{KCl}, 6.7 \mathrm{~mm}$ $\mathrm{MgCl}_{2}, 200 \mu \mathrm{mol} \mathrm{dNTPs}$ and $0.5 \mathrm{U}$ of Taq polymerase in a final reaction volume of $20 \mu \mathrm{l}$. Thermal cycling parameters were as follows: denaturation at $94{ }^{\circ} \mathrm{C}$ for $4 \mathrm{~min} ; 30$ cycles of $94^{\circ} \mathrm{C}$ for $1 \mathrm{~min} ; 64^{\circ} \mathrm{C}$ for $1 \mathrm{~min} ; 72^{\circ} \mathrm{C}$ for $1 \mathrm{~min}$; and final extension at $72{ }^{\circ} \mathrm{C}$ for $10 \mathrm{~min}$. The amplified products were resolved on a $9 \%$ polyacrylamide gel with ethidium bromide staining under ultraviolet light to verify their size and quantity. The presence of heterozygotes for c.35delG, c.235delC and c.167delT was detected by the appearance of two separate bands (for the wild type and for the mutant allele): amplified fragments sized 89 and $88 \mathrm{bp}$ for c.35delG, 79 and $78 \mathrm{bp}$ for c.235delC, and 83 and $82 \mathrm{bp}$ for c.167delT, respectively (Supplementary Figure 1). The heterozygous status was confirmed by direct sequencing of amplified fragments (739 bp) of the GJB2 encoding region using the following primers:

739 bp F 5'-CATTCGTCTTTTCCAGAGCAAACC-3',

739 bp R 5'- ACAACTGGGCAATGCGTTAAACTG $-3^{\prime}$.

Primers were designed at the Laboratory of Molecular Human Genetics (Institute of Biochemistry and Genetics, Ufa Research Center, Russian Academy of Sciences). Sequencing was carried out using the BigDye terminator V3.1 cycle sequencing kit (Applied Biosystems, Foster City, CA, USA) and the ABI 310 DNA sequencer (Applied Biosystems).

\section{Maps construction}

Spatial carrier frequency distribution maps for mutations c.35delG and c.235delC were constructed on the basis of data obtained in this study and on the basis of corresponding data on different populations of Eurasia extracted from the literature sources available at the end of 2009 (Supplementary Table and References).

Maps construction was carried out by means of package SURFER 9.0 Golden Software, Inc., Golden, CO, USA. Data were regularized by the Kriging method with subsequent matrix smoothing and a cubic spline.

\section{RESULTS AND DISCUSSION}

There are numerous data on carrier frequencies of basic GJB2 mutations c.35delG, c.167delT and c.235delC in various populations of the world. However, until recently, such data with regard to populations on territories of the Former Soviet Union have been limited. ${ }^{14,33-36}$

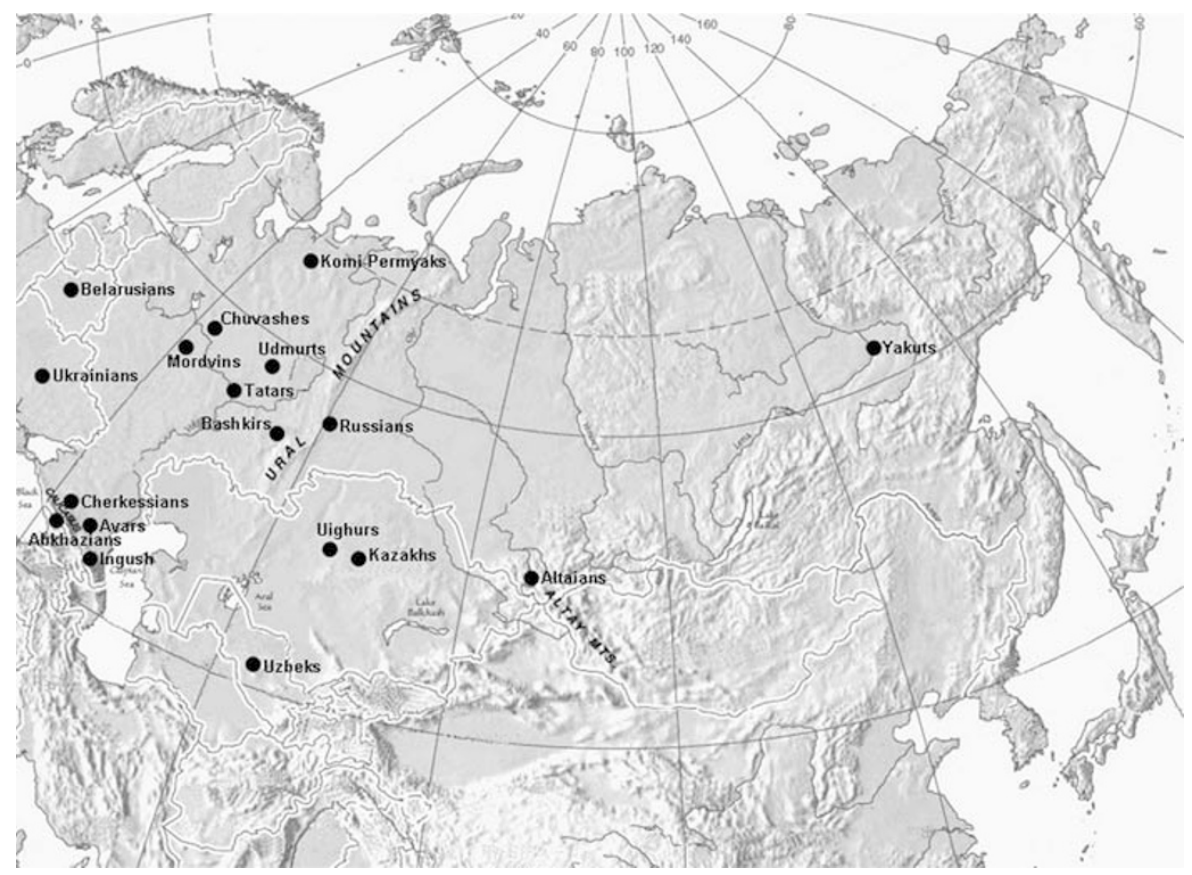

Figure 1 Places of location of the populations under study. 
Table 1 Carrier frequencies of the c.35delG, c.167delT and c.235delC mutations among the studied Eurasian populations

\begin{tabular}{|c|c|c|c|c|c|c|}
\hline \multirow[b]{2}{*}{ Populations } & \multirow{2}{*}{$\begin{array}{l}\text { Linguistic } \\
\text { affiliations: } \\
\text { family/group }\end{array}$} & \multirow[b]{2}{*}{ Regions } & \multirow[b]{2}{*}{ N } & \multicolumn{3}{|c|}{$\begin{array}{l}\text { Carriers/tested individuals } \\
\text { Carrier frequencies }\end{array}$} \\
\hline & & & & c.35de/G & c.167delT & c.235delC \\
\hline \multicolumn{7}{|l|}{ Eastern Europe } \\
\hline Belarusians & Indo-European/Slavic & Belarus & 97 & $\begin{array}{c}6 / 97 \\
0.062\end{array}$ & 0/97 & $0 / 97$ \\
\hline \multicolumn{7}{|c|}{ Volga-Ural region/Russian Federation } \\
\hline Russians & Indo-European/Slavic & Yekaterinburg & 92 & $\begin{array}{l}2 / 92 \\
0.022\end{array}$ & $0 / 92$ & $0 / 92$ \\
\hline Bashkirs & Altaic/Turkic & Republic of Bashkortostan & 400 & $\begin{array}{l}1 / 400 \\
0.003\end{array}$ & $0 / 400$ & $0 / 400$ \\
\hline Mordvins & Uralic/Finno-Ugric & Republic of Mordovia & 80 & $\begin{array}{c}5 / 80 \\
0.062\end{array}$ & $0 / 80$ & $\begin{array}{c}1 / 80 \\
0.012\end{array}$ \\
\hline Udmurts & Uralic/Finno-Ugric & Republic of Udmurtia & 80 & $\begin{array}{l}3 / 80 \\
0.037\end{array}$ & $0 / 80$ & $0 / 80$ \\
\hline Komi-Permyaks & Uralic/Finno-Ugric & Komi-Permyak Autonomous Okrug & 80 & $0 / 80$ & $\begin{array}{c}2 / 80 \\
0.025\end{array}$ & $0 / 80$ \\
\hline \multicolumn{7}{|l|}{ Central Asia } \\
\hline Kazakhs & Altaic/Turkic & Kazakhstan & 240 & $\begin{array}{l}2 / 240 \\
0.008\end{array}$ & $0 / 240$ & $\begin{array}{l}1 / 240 \\
0.004\end{array}$ \\
\hline Uighurs & Altaic/Turkic & Kazakhstan & 116 & $\begin{array}{l}1 / 116 \\
0.009\end{array}$ & $0 / 116$ & $0 / 116$ \\
\hline Cherkessians & Caucasian/North Caucasian & North Caucasus/Karachay-Cherkess Republic, Russian Federation & 80 & $\begin{array}{l}1 / 80 \\
0.013\end{array}$ & $0 / 80$ & $0 / 80$ \\
\hline Ingushes & Caucasian/North Caucasian & North Caucasus/Ingush Republic, Russian Federation & 80 & $0 / 80$ & $0 / 80$ & $0 / 80$ \\
\hline \multicolumn{7}{|c|}{ Siberia/Russian Federation } \\
\hline Yakuts & Altaic/Turkic & East Siberia/Republic of Sakha (Yakutia) & $247(120)$ & $\begin{array}{l}1 / 247 \\
0.004\end{array}$ & $0 / 120$ & $0 / 120$ \\
\hline Altaians & Altaic/Turkic & South Siberia/Republic of Altai & 230 & $0 / 230$ & $0 / 230$ & $\begin{array}{l}8 / 230 \\
0.035\end{array}$ \\
\hline
\end{tabular}

The data obtained in this study allow, to a certain extent, to fill the gap in information on the prevalence of the c.35delG, c.167delT and c.235delC mutations of the GJB2 gene on the vast territories of Eurasia.

Carrier frequencies of these mutations in 18 various populations living in the territory of Eurasia (Eastern Europe, the Volga-Ural region of Russia, Central Asia, Caucasus and Siberia) are presented in Table 1.

\section{Mutation c.35delG}

Mutation c.35delG in the GJB2 gene in homozygous and compoundheterozygous conditions is the major cause of non-syndromic recessive hearing loss in most European populations. It accounts for approximately $40-50 \%$ of overall mutant alleles of the GJB2 gene in deaf patients. ${ }^{37}$ Earlier, the large-scale research covering 17 European countries demonstrated that the average carrier frequency of c.35delG in Europe was $1.96 \%$ ( 1 of 51), with a variation from $1.26 \%$ ( 1 of 79 ) in Central and northern Europe to $2.86 \%$ (1 of 35 ) in southern Europe. ${ }^{7}$ Further, the gradient of increase in c.35delG frequency from north to south has been confirmed in the meta-analysis of the carrier frequency of c.35delG in various European populations. ${ }^{38}$ High carrier frequency of c.35delG has been shown in Mediterranean populations: Greece $(3.5 \%)$, southern Italy $(4.0 \%)$ and France $(3.4 \%) .{ }^{39}$ The majority of studies investigating the origin and estimating the age of the c.35delG mutation have been conducted on the Mediterranean region: the countries of southern Europe and the Middle East. 
The hypothesis about a single origin for c.35delG somewhere in the Mediterranean region or in the Middle East (founder effect) has been suggested and subsequently confirmed. Estimations of the age of c.35delG revealed that it occurred at least 10000-14000 years ago and then spread throughout Europe along two Neolithic population movement routes. ${ }^{7,26,27,30}$ Recent meta-analysis of the c.35delG prevalence, performed by reviewing literature data from 1998 to 2008, has shown that mean regional carrier frequencies of c.35delG mutation were $1.89,1.52,0.93,1$ and $0.64 \%$ for European, American, Asian, Oceanic and African populations, respectively. The south-to-north European decrease gradient in the carrier frequency of c.35delG (from 2.48 to $1.53 \%$ ) was confirmed in this study and a west-to-east Asian gradient (from 1.48 to $0.1 \%$ ) was also suggested. ${ }^{40}$

Screening of the c.35delG mutation performed by ourselves in two East-European populations (Ukrainians and Belarusians) revealed high carrier frequencies of this mutation: $3.3 \%$ in Ukrainians and $6.2 \%$ in Belarusians. We also studied the carrier frequency of c.35delG among various indigenous populations of the Volga-Ural region of Russia (Bashkirs, Tatars, Chuvashes, Mordva, Udmurts, KomiPermyaks), as well as collected samples from Russian individuals living in the Volga-Ural region. The Volga-Ural region of Russia is situated in the border of Europe and Asia and during historical times was a place of interaction of many ethnic groups-Ugric tribes of western Siberia, north Finns of Eastern Europe, Indo-Iranians of the Middle East, Turkic-speaking people of southern Siberia and Altai and, later, nomadic Tatar-Mongolian tribes and Slavic people of Central and Western Europe. ${ }^{41,42}$

In Turkic-speaking populations of the Volga-Ural region, mutation c.35delG was found with frequencies of $1,0.3$ and $0 \%$ in Tatars, Bashkirs and Chuvashes, respectively. Finno-Ugric populations of the Volga-Ural region demonstrated an extremely high carrier frequency of c.35delG mutation in Mordva and Udmurts (6.2 and 3.7\%, respectively) and absence of c.35delG in Komi-Permyaks. High carrier frequency of c.35delG (4.4\%), revealed earlier in Estonians (FinnoUgric population), was an obvious exception for the populations of northern Europe with low frequencies of c.35delG. ${ }^{7}$ Our data on c.35delG frequency in populations of the Volga-Ural region and data from other researchers ${ }^{33-35}$ demonstrate considerable variability of the c.35delG mutation carrier frequency among native populations of the Volga-Ural region. The carrier frequency of c.35delG revealed in Russians was $2.2 \%$, which is comparable to the data obtained by other researchers studying individuals from Russian populations of central regions of Russia. ${ }^{33-36}$

In Turkic populations of Central Asia (Kazakhs, Uighurs, Uzbeks), the mutation c.35delG was found with low frequency in Kazakhs $(0.8 \%)$ and Uighurs $(0.9 \%)$, but was not revealed in Uzbeks. In Turkic populations of Siberia (Yakuts, Altaians), c.35delG was discovered with rather low frequency $(0.4 \%)$ in the population of Yakuts, but was not found in the population of Altaians.

The territory of north Caucasus in the past was one of the most significant passages during human migration in the territory of Eurasia. This region is characterized by a wide variety of ethnic populations, complicated history of the formation of ethnic groups and high genetic diversity. ${ }^{43}$ Among the populations of the north Caucasus studied (Abkhazians, Avars, Cherkessians, Ingushes), the mutation c.35delG was revealed only in Abkhazians (3.8\%) and Cherkessians (1.3\%).

The spatial distribution of the c.35delG carrier frequencies on the territory of Eurasia constructed on the basis of data obtained during this study and extracted from appropriate literature sources available at the end of 2009 is presented in Figure 2.

This spatial distribution of c.35delG carrier frequencies confirms a Eurasian decreasing gradient in the carrier frequency of c.35delG from west to east: high frequency of c.35delG in populations of Eastern Europe (Belarusians, Ukrainians), intermediate frequencies in populations of the Volga-Ural region and Central Asia and minimal frequency of c.35delG in Yakuts from eastern Siberia. The west-toeast decreasing gradient observed on the c.35delG mutation carrier frequency, in general, corresponds to the data of the comparative analysis of mtDNA haplogroups lineages in Finno-Ugric- and Turkicspeaking populations of northern Eurasia, where the west-to-east gradient of decrease of the west-Eurasian component in the gene pool of these populations was shown from Eastern Europe to Siberia. ${ }^{44}$ Our data on the prevalence of c.35delG mutation among

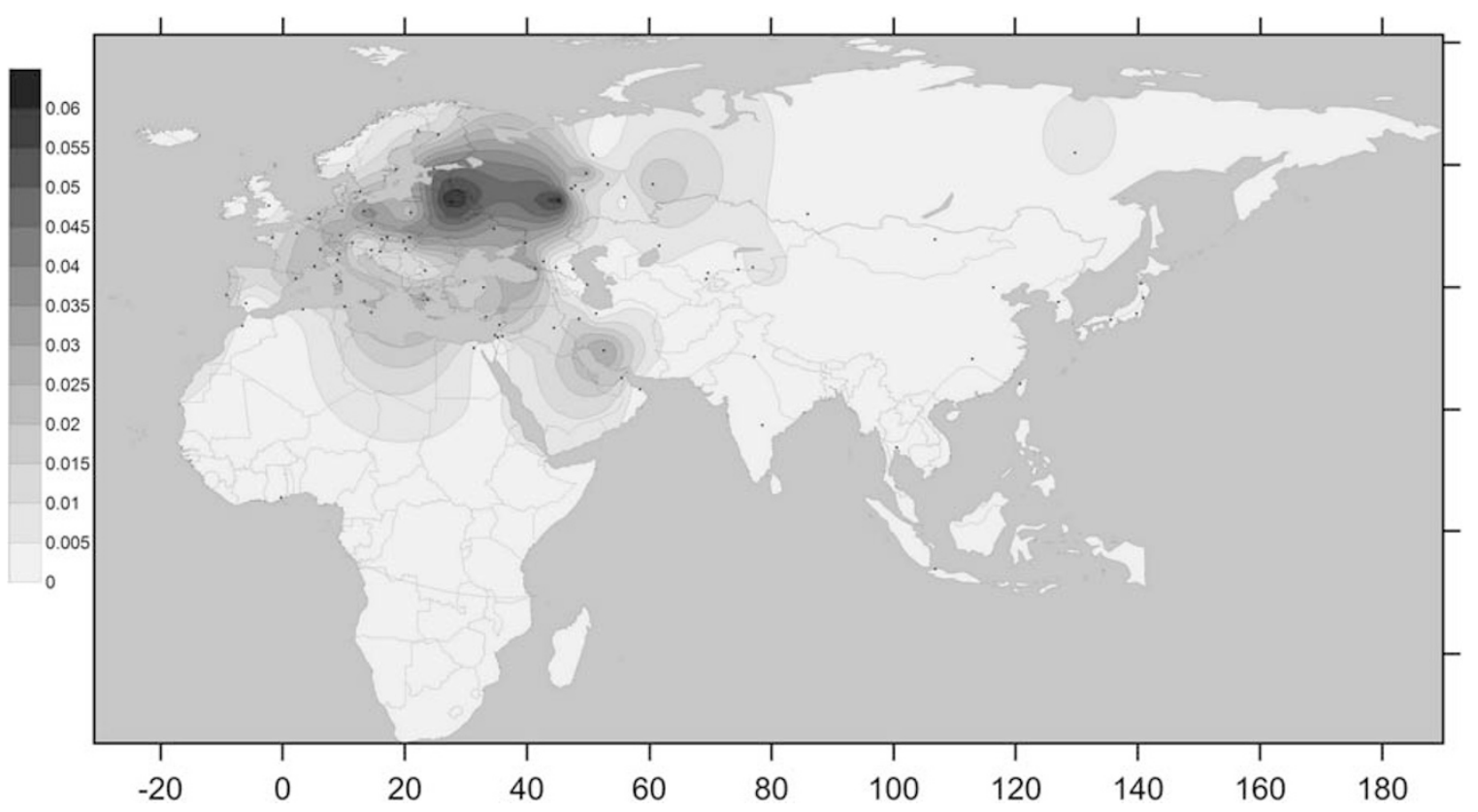

Figure 2 Spatial distribution of the c.35delG carrier frequency in Eurasia. Data from Supplementary Table were used for map construction. 
various populations settling down in extensive territories of Eurasia allow further elucidation of present-day concepts of the southern origin (south Europe/Middle East) of the c.35delG mutation.

\section{Mutation c.167delT}

In the Ashkenazi Jewish population, the carrier rate of c.167delT mutation was $4.03 \%$, reaching up to $7.5 \%$ in some samples, which is rare in many populations. The conservation of haplotypes surrounding the c.167delT mutation suggests a single origin of this allele. ${ }^{17-19}$ Mutation c.167delT in Eurasia prevails mostly in the territories of the Middle East, although this mutation is sporadically found in other regions as well. ${ }^{20,21}$ Mutation c.167delT was only found in two VolgaUral region populations-Chuvashes (1\%) and Komi-Permyaks $(2.5 \%)$. These data may confirm either distribution of chromosomes with c.167delT mutation that originated from the Middle East among Chuvashes and Komi-Permyaks, or an independent origin of c.167delT, as this mutation was not found in people neighboring Chuvashes and Komi-Permyaks.

\section{Mutation c.235delC}

Cytosine deletion in nucleotide 235 (c.235delC) of the GJB2 gene has been described as a novel mutation in patients with hearing loss from Japan. ${ }^{45}$ Further analysis of the GJB2 gene in Asian countries revealed that mutation c.235delC is common in Japan, China, Korea, Thailand and Mongolia, with frequency ranging from 1.6 to $20.3 \%$ among chromosomes in deaf patients. The carrier frequency of c.235delC varies from 0.8 to $1.3 \%$ among East Asian populations, ${ }^{11-13,15,16,29,46}$ and c.235delC is practically absent in populations of southern Asia. ${ }^{23,25,47}$ c.235delC is revealed only sporadically in other Eurasian populations with a complex ethnic composition.

In the territory of the former Soviet Union, mutation c.235delC was revealed with a frequency of 3.5\% in Altaians (Southern Siberia), 1.3\% in Mordva (the Volga-Ural region), $1.7 \%$ in Avars, which is a local group in Caucasus with complex ethnogenesis, and with a rather low frequency in Kazakhs (0.4\%; Kazakhstan, Central Asia).

Previous studies demonstrated a common ancestral origin of mutation c.235delC that is widespread in East Asian populations
(China, Korea, Japan, Mongolia) and a roughly estimated age of c.235delC is to be about 11500 years old. ${ }^{12,13,29}$ Yan et al. ${ }^{29}$ hypothesized that c.235delC could arise in regions of the Baikal Lake and then extend to Mongolia, China, Korea and Japan through subsequent migrations. Earlier, we have found a high carrier frequency of c.235delC (4.6\%, 6 of 130) in Turkic-speaking Altaians-indigenous people of the Altai-Sayan region-which allowed us to suggest that the Altai-Sayan region, which was a zone of contacts and active migrations of various ethnic groups in the historical past, could be one of the founder sources for the c.235delC mutation widespread in Asia. ${ }^{14}$

The increase in the number of Altaian DNA samples analyzed in this study to 230 by involvement of individuals from the majority of territorial areas of the Republic of Altai, however, has led to some decrease in the carrier frequency of c.235delC in Altaians from $4.6 \%$ ( 6 of 130 ) to $3.5 \%$ ( 8 of 230 ). It is interesting that mutation c. $235 \mathrm{delC}$ has not been revealed in Turkic-speaking Yakuts (Eastern Siberia), although being based on archeological, ethnographic and linguistic data; furthermore, taking into consideration data on mtDNA and Y-chromosome analysis, it was supposed that Yakuts migrated to the north from their initial settlement in the area of the Baikal Lake under pressure of the Mongol expansion between the thirteenth and fifteenth centuries $\mathrm{AD}^{48}$

Spatial distribution of carrier frequency of c.235delC in the territory of Eurasia demonstrates an east-to-west decreasing gradient in the frequency of c.235delC and shows that the Altai-Sayan region could be one of the most probable regions of origin of this mutation (Figure 3 ).

At present, our data on distribution of the c.235delC mutation in people occupying territories around the Baikal Lake and the Altai-Sayan region are limited only to Altaians. In future, we hope to expand studies among other indigenous people of the Altai-Sayan region and neighboring territories to verify the c.235delC mutation prevalence and to further define the probable area of origin of c.235delC mutation.

In summary, this study reports on the carrier frequency of three common deafness-causing mutations of the GJB2 gene in 18 ethnic groups from Eurasia, and thereby fills a gap in knowledge regarding the pattern of geographical distribution of GJB2 mutations. Despite probable bias caused by different sizes of the samples screened in this

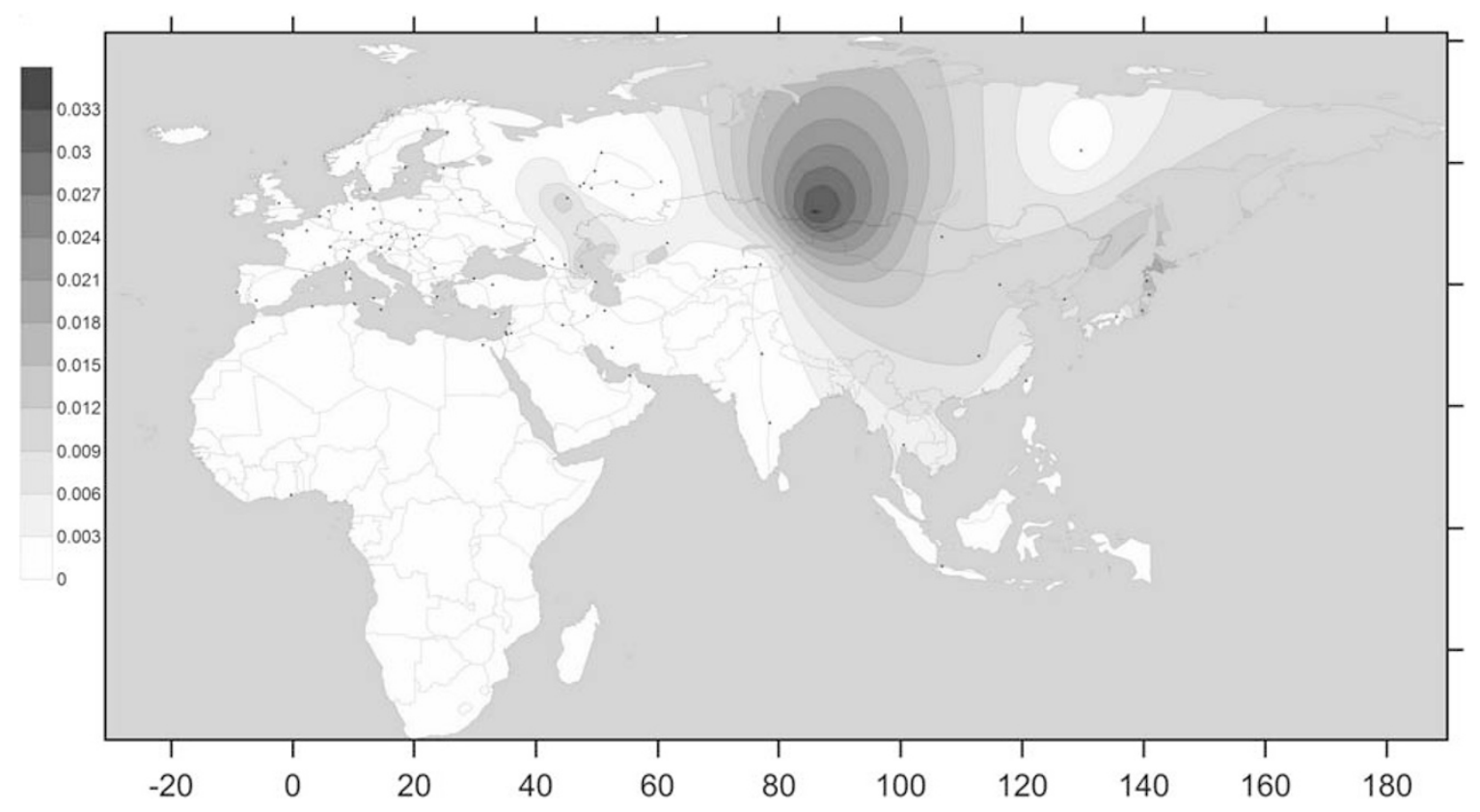

Figure 3 Spatial distribution of the c.235delC carrier frequency in Eurasia. Data from Supplementary Table were used for map construction. 
study (from 60 to 400 subjects), the obtained data provide novel insights into a specification of prevalence of major recessive mutations c.35delG, c.235delC and c.167delT of the GJB2 gene in populations of Eurasia. The character of c.35delG and c.235delC mutation prevalence in the studied ethnic groups can provide additional evidence of a prospective role of the founder effect in their origin and help to understand the prevalence of these mutations in populations around the world. Research studies such as these are also important for the development of appropriate screening assays of GJB2 gene mutations in various ethnic groups for early detection of hereditary forms of hearing loss and design of preventive activities.

\section{ACKNOWLEDGEMENTS}

This study was supported by grants from the Russian Foundation for Humanities: Ural 08-06-84602a/Y and No. 07-06-00765a; the Russian Foundation for Basic Research, No. 09-04-01123-a, MK-2575.2008.04.; grants from the Siberian Branch of the Russian Academy of Science (Novosibirsk, 20042009), the Federal Program for 2010-2012 (No. 02.740.11.0701), the State contract No. P325 and the State contract No. P601.

1 Marazita, M., Ploughman, L., Rawlings, B., Remington, E., Arnos, K. \& Nance, W. Genetic epidemiological studies of early-onset deafness in the US school-age population. Am. J. Med. Genet. 46, 486-491 (1993).

2 Petit, C., Levilliers, J. \& Hardelin, J. Molecular genetics of hearing loss. Annu. Rev. Genet. 35, 589-646 (2001).

3 Van Camp, G. \& Smith, R. J. H. Hereditary hearing loss homepage. URL http:// hereditaryhearingloss.org.

4 Kikuchi, T., Kimura, R., Paul, D. \& Adams, J. Gap junctions in the rat cochlea: immunohistochemical and ultrastructural analysis. Anat. Embryol. (Berl.) 191, 101-118 (1995).

5 Ballana, E., Ventayol, M., Rabionet, R., Gasparini, P. \& Estivill, X. Connexins and deafness homepage World wide web URL http://davinci.crg.es/deafness/index.php (2010).

6 Kenneson, A., Van Naarden Braun, K. \& Boyle, C. GJB2 (connexin 26) variants and nonsyndromic sensorineural hearing loss: a HuGE review. Genet. Med. 4, 258-274 (2002).

7 Gasparini, P., Rabionet, R., Barbujani, G., Melchionda, S., Petersen, M., BrondumNielsen, K. et al. High carrier frequency of the 35delG deafness mutation in European populations. Eur. J. Hum. Genet. 8, 19-23 (2000).

8 Rabionet, R., Zelante, L., López-Bigas, N., D’Agruma, L., Melchionda, S., Restagno, G. et al. Molecular bases of childhood deafness resulting from mutations in the GJB2 (connexin 26) gene. Hum. Genet. 106, 40-44 (2000).

9 Lucotte, G., Bathelier, C. \& Champenois, T. PCR test for diagnosis of the common GJB2 (connexin 26) 35delG mutation on dried blood spots and determination of the carrier frequency in France. Mol. Cell. Probes. 15, 57-59 (2001).

10 Tekin, M., Akar, N., Cin, S., Blanton, S., Xia, X., Liu, X. et al. Connexin 26 (GJB2) mutations in the Turkish population: implications for the origin and high frequency of the 35delG mutation in Caucasians. Hum. Genet. 108, 385-389 (2001).

11 Park, H., Hahn, S., Chun, Y., Park, K. \& Kim, H. Connexin26 mutations associated with nonsyndromic hearing loss. Laryngoscope 110, 1535-1538 (2000).

12 Liu, X., Xia, X., Ke, X., Ouyang, X., Du, L., Liu, Y. et al. The prevalence of connexin 26 (GJB2) mutations in the Chinese population. Hum. Genet. 111, 394-397 (2002).

13 Ohtsuka, A., Yuge, I., Kimura, S., Namba, A., Abe, S. \& Van Laer, L. GJB2 deafness gene shows a specific spectrum of mutations in Japan, including a frequent founder. Hum. Genet. 112, 329-339 (2003).

14 Posukh, O., Pallares-Ruiz, N., Tadinova, V., Osipova, L., Claustres, M. \& Roux, A. First molecular screening of deafness in the Altai Republic population. BMC Med. Genet. 24, 6-12 (2005).

15 Han, S., Park, H., Kang, E., Ryu, J., Lee, A., Yang, Y. et al. Carrier frequency of GJB2 (connexin-26) mutations causing inherited deafness in the Korean population. J. Hum. Genet. 53, 1022-1028 (2008).

16 Dai, P., Yu, F., Han, B., Liu, X., Wang, G., Li, Q. et al. GJB2 mutation spectrum in 2063 Chinese patients with nonsyndromic hearing impairment. J. Transl. Med. 14, 7-26 (2009).

17 Morell, R., Kim, H., Hood, L., Goforth, L., Friderici, K., Fisher, R. et al. Mutations in the connexin 26 gene (GJB2) among Ashkenazi Jews with nonsyndromic recessive deafness. N. Engl. J. Med. 339, 1500-1505 (1998).

18 Sobe, T., Erlich, P., Berry, A., Korostichevsky, M., Vreugde, S., Avraham, K. et al. High frequency of the deafness-associated 167delT mutation in the connexin 26 (GJB2) gene in Israeli Ashkenazim. Am. J. Med. Genet. 86, 499-500 (1999).

19 Lerer, I., Sagi, M., Malamud, E., Levi, H., Raas-Rothschild, A. \& Abeliovich, D. Contribution of connexin 26 mutations to nonsyndromic deafness in Ashkenazi patients and the variable phenotypic effect of the mutation 167delT. Am. J. Med. Genet. 95, 53-56 (2000).
20 Mahasneh, A. \& Battah, R. Prevalence of connexin 26 mutations in patients from Jordan with non syndromic hearing loss. Int. J. Hum. Genet. 6, 119-124 (2006).

21 Niceta, M., Fabiano, C., Sammarco, P., Piccione, M., Antona, V., Giuffre, M. et al. Epidemiological study of nonsyndromic hearing loss in Sicilian newborns. Am. J. Med. Genet. 143A, 1666-1670 (2007).

22 Ramchander, P., Nandur, V., Dwarakanath, K., Vishnupriya, S. \& Padma, T. Prevalence of Cx26 (GJB2) gene mutation causing recessive nonsyndromic hearing impairment in India. Int. J. Hum. Genet. 5, 241-246 (2005).

23 Minárik, G., Ferák, V., Feráková, E., Ficek, A., Poláková, H. \& Kádasi, L. High frequency of GJB2 mutation W24X among Slovak Romany (Gypsy) patients with non-syndromic hearing loss (NSHL). Gen. Physiol. Biophys. 22, 549-556 (2003).

24 Hamelmann, C., Amedofu, G., Albrecht, K., Muntau, B., Gelhaus, A., Brobby, G. et al. Pattern of connexin 26 (GJB2) mutations causing sensorineural hearing impairment in Ghana. Hum. Mutat. 18, 84-85 (2001).

25 Wattanasirichaigoon, D., Limwongse, C., Jariengprasert, C., Yenchitsomanus, P., Tocharoenthanaphol, C., Thongnoppakhun, W. et al. High prevalence of V37I genetic variant in the connexin-26 (GJB2) gene among non-syndromic hearing-impaired and control Thai individuals. Clin. Genet. 66, 452-460 (2004).

26 Van Laer, L., Coucke, P., Mueller, R., Caethoven, G., Flothmann, K., Prasad, S. et al. A common founder for the 35delG GJB2 gene mutation in connexin 26 hearing impairment. J. Med. Genet. 38, 515-518 (2001).

27 Rothrock, C., Murgia, A., Sartorato, E., Leonardi, E., Wei, S., Lebeis, S. et al. Connexin 26 35delG does not represent a mutational hotspot. Hum. Genet. 113, 18-23 (2003).

28 RamShankar, M., Girirajan, S., Dagan, O., Ravi Shankar, H., Jalvi, R., Rangasayee, R. et al. Contribution of connexin26 (GJB2) mutations and founder effect to nonsyndromic hearing loss in India. J. Med. Genet. 40, e68 (2003)

29 Yan, D., Park, H., Ouyang, X., Pandya, A., Doi, K., Erdenetungalag, R. et al. Evidence of a founder effect for the 235delC mutation of GJB2 (connexin 26) in East Asians. Hum. Genet. 114, 44-50 (2003).

30 Kokotas, H., Van Laer, L., Grigoriadou, M., Iliadou, V., Economides, J., Pomoni, S. et al. Strong linkage disequilibrium for the frequent GJB2 35delG mutation in the Greek population. Am. J. Med. Genet. 146A, 2879-2884 (2008).

31 Nance, W., Liu, X. \& Pandya, A. Relation between choice of partner and high frequency of connexin-26 deafness. Lancet. 356, 500-501 (2000).

32 Common, J., Di, W., Davies, D. \& Kelsell, D. Further evidence for heterozygote advantage of GJB2 deafness mutations: a link with cell survival. J. Med. Genet. 41, 573-575 (2004).

33 Anichkina, A., Kulenich, T., Zinchenko, S., Shagina, I., Polyakov, A., Ginter, E. et al. On the origin and frequency of 35delG allele in GJB2-linked deafness in Europe. Eur. J. Hum. Gen. 9, 151 (2001).

34 Khidiyatova, I., Dzhemileva, L., Khabibulin, R. \& Khusnutdinova, E. Frequency of the 35delG mutation of the connexin 26 gene (GJB2) in patients with non-syndromic autosome-recessive deafness from Bashkortostan and in ethnic groups of the Volga-Ural region. Mol. Biol. (Mosk). 36, 438-441 (2002).

35 Zinchenko, R., El'chinova, G., Galkina, V., Kirillov, A., Abrukova, A., Petrova, N. et al. Genetic differentiation ethnic groups of Russia on genes of hereditary disorders. Med. Genetika. 6, 29-37 (2007)[in Russian].

36 Shokarev, R., Amelina, S., Kriventsova, N., Elchinova, G., Khlebnikova, O., Bliznetz, E. et al. Genetic-epidemiological and molecular study of hereditary deafness in Rostov province. Med. Genetika. 4, 556-567 (2005)[in Russian].

37 Petersen, M. \& Willems, P. Non-syndromic, autosomal-recessive deafness. Clin. Genet. 69, 371-392 (2006)

38 Lucotte, G. \& Mercier, G. Meta-analysis of GJB2 mutation 35delG frequencies in Europe. Genet. Test. 5, 149-152 (2001).

39 Lucotte, G. High prevalences of carriers of the 35 delG mutation of connexin 26 in the Mediterranean area. Int. J. Pediatr. Otorhinolaryngol. 71, 741-746 (2007).

40 Mahdieh, N. \& Rabbani, B. Statistical study of 35delG mutation of GJB2 gene: a meta-analysis of carrier frequency. Int. J. Audiol. 48, 363-370 (2009).

41 Alekseev, V. The Geography of Human Races. 1st edn (Nauka, Moscow, 1974).

42 Kuzeev, R. The Peoples of the Volga and Ural Regions. 1st edn (Nauka, Moscow, 1985)

43 Nasidze, I., Ling, E., Quinque, D., Dupanloup, I., Cordaux, R., Rychkov, S. et al. Mitochondrial DNA and Y-chromosome variation in the Caucasus. Ann. Hum. Genet. 68, 205-221 (2004).

44 Khusnutdinova, E. \& Kutuev, I. in Molecular Polymorphism of Man: Structural and Functional Individual Multiformity of Biomacromolecules. (eds Varfolomyev, S. \& Zaikov, G.) 40-51 (Nova publishers, New York, 2009).

45 Fuse, Y., Doi, K., Hasegawa, T., Sugii, A., Hibino, H. \& Kubo, T. Three novel connexin26 gene mutations in autosomal recessive non-syndromic deafness. Neuroreport 10, 1853-1857 (1999).

46 Kudo, T. Ikeda, K., Kure, S., Matsubara, Y. Oshima, T., Watanabe, K et al. Novel mutations in the connexin 26 gene (GJB2) responsible for childhood deafness in the Japanese population. Am. J. Med. Genet. 90, 141-145 (2000).

47 Snoeckx, R., Huygen, P., Feldmann, D., Marlin, S., Denoyelle, F., Waligora, J. et al. GJB2 (connexin 26) mutations are not a major cause of hearing loss in the indonesian population. Am. J. Med. Genet. A. 135, 126-129 (2005).

48 Pakendorf, B., Novgorodov, I., Osakovskij, V., Danilova, A., Protod'jakonov, A. \& Stoneking, M. Investigating the effects of prehistoric migrations in Siberia: genetic variation and the origins of Yakuts. Hum. Genet. 120, 334-353 (2006). 